\title{
POLA PERTUMBUHAN DAN PRODUKSI TANAMAN CABAI MERAH KERITING (Capsicum annuum L.) AKIBAT APLIKASI KALIUM NITRAT PADA DAERAH DATARAN RENDAH
}

\author{
Satrio Tri Handono, Kus Hendarto \& Muhammad Kamal \\ Jurusan Agroteknologi, Fakultas Pertanian Universitas Lampung \\ Jl. Prof. Soemantri Brodjonegoro, No.1, Bandar Lampung 35145 \\ Email : satriojawa@rocketmail.com
}

\begin{abstract}
ABSTRAK
Cabai (Capsicum annuиm L.) merupakan salah satu komoditas hortikultura yang memiliki nilai ekonomi penting di Indonesia, sehingga budidaya cabai sangat menarik bagi petani. Permintaan produk cabai cenderung meningkat terus sehingga dapat diandalkan sebagai komoditas nonmigas. Seiring dengan permintaan yang meningkat sehingga kurangnya pasokan yang tersedia maka peningkatan luas tanam diarahkan untuk mencapai keseimbangan pasokan dan permintaan. Salah satu usaha yang dapat dilakukan adalah melakukan teknik budidaya yang baik dan benar sehingga hasil yang diperoleh optimal. Salah satu aspek yang penting dalam budidaya tanaman adalah pemupukan.Penelitian ini bertujuan untuk mengetahui respon pola pertumbuhan tanaman cabai merah terhadap aplikasi Kalium Nitrat dan untuk mengetahui respon komponen hasil cabai terhadap pemberian Kalium Nitrat dengan konsentrasi berbeda. Penelitian ini dilaksanakan di Desa Sukabanjar Kecamatan Gedong Tataan Kabupaten Pesawaran dari Oktober 2011 sampai April 2012. Penelitian disusun menggunakan Rancangan acak kelompok dengan perlakuan tunggal yaitu konsentrasi $\mathrm{KNO}_{3}$ yang terdiri atas : 0, 2, 4, 6, $8 \mathrm{~g} \mathrm{l}^{-1}$, dengan 3 kali ulangan. Seluruh data yang diperoleh dianalisis ragam. Homogenitas ragam diuji dengan uji Bartlett sedangkan aditivitas diuji dengan uji Tukey. Analisis data dilanjutkan dengan uji polinomial ortogonal pada taraf 5\%. Hasil penelitian menunjukan bahwa pada pola pertumbuhan vegetatif untuk variabel tinggi tanaman dan tingkat percabangan aplikasi kalium nitrat pada berbagai taraf konsentrasi yaitu : 0, 2, 4, 6, $8 \mathrm{~g} \mathrm{l}^{-1}$ tidak memberikan pengaruh yang nyata dan pada pemberian kalium nitrat dengan konsentrasi 4, 6, $8 \mathrm{~g} \mathrm{l}^{-1}$ meningkatkan jumlah bunga di tanaman cabai. Peningkatan jumlah buah tertinggi terdapat pada aplikasi kalium nitrat dengan konsentrasi $8 \mathrm{~g} \mathrm{l}^{-1}$, sedangkan pada bobot buah total tertinggi terjadi pada konsentrasi $6 \mathrm{~g} \mathrm{l}^{-1}$.
\end{abstract}

Kata kunci : Kalium nitra, $\mathrm{KNO}_{3}$, peningkatan produksi cabai, tanaman cabai.

\section{PENDAHULUAN}

Cabai (Capsicum annuum L.) merupakan salah satu komoditas hortikultura yang memiliki nilai ekonomi penting di Indonesia. Nilai ekonominya yang tinggi merupakan daya tarik pengembangan budidaya cabai bagi petani. Permintaan produk cabai cenderung meningkat terus sehingga dapat diandalkan sebagai komoditas nonmigas (Rukmana, 1996).

Untuk memenuhi permintaan pasar yang semakin meningkat, usaha yang dapat dilakukan guna peningkatan produksi cabai merah yang tinggi adalah melakukan teknik budidaya yang baik dan benar sehingga hasil yang diperoleh optimal, salah satu unsur yang perlu membantu produksi adalah kalium.Kalium diserap tanaman dalam bentuk $\mathrm{K}^{+}$. Ion ini dengan mudah disalurkan dari organ dewasa ke organ muda. Kalium merupakan pengaktif dari sejumlah besar enzim yang penting untuk respirasi dan fotosintesis.

Kalium juga dapat mengaktifkan enzim yang membentuk pati. Tanaman yang kekurangan kalium akan mengakumulasi karbohidrat lebih rendah karena fotosintesis berjalan lambat. Kekurangan kalium juga menyebabkan daun menjadi kuning, batang menjadi lemah, dan rentan terhadap hama dan penyakit (Salisbury dan Ross, 1995). Penelitian ini bertujuan untuk mengetahui respon pola pertumbuhan tanaman cabai merah terhadap aplikasi Kalium Nitrat dan mengetahui respon komponen hasil cabai terhadap pemberian Kalium Nitrat dengan konsentrasi berbeda.

\section{BAHAN DAN METODE}

Penelitian ini dilaksanakan di Desa Sukabanjar Kecamatan Gedong Tataan Kabupaten Pesawaran dari Oktober 2011 sampai April 2012. Bahan yang digunakan adalah benih cabai merah varietas TM 999, pupuk kandang kambing, $\mathrm{NPK}$ mutiara, $\mathrm{KNO}_{3}$, Plant Catalyst, dolomit, dan Tanah top soil. Alat-alat yang digunakan tali rafia, polibag kecil, meteran, cangkul, arit, gembor, hand sprayer, ember, gayung, timbangan digital, gunting, lanjaran, label, alat tulis, dan plastik. 
Penelitian ini disusun secara tunggal dengan faktor taraf konsentrasi KNO3 yaitu: $0 \mathrm{~g} \mathrm{l}^{-1}, 2 \mathrm{~g} \mathrm{l}^{-1}, 4$ $\mathrm{g} \mathrm{l}^{-1}, 6 \mathrm{~g} \mathrm{l}^{-1}, 8 \mathrm{~g} \mathrm{l}^{-1}$, diterapkan dalam rancangan kelompok teracak sempurna (RKTS) dengan 3 kali ulangan. Seluruh data yang diperoleh dianalisis ragam. Homogenitas ragam diuji dengan uji Bartlett sedangkan aditivitas diuji dengan uji Tukey. Analisis data dilanjutkan dengan uji polinomial ortogonal.

Pengolahan tanah bertujuan mengubah struktur tanah yang bergumpal-gumpal menjadi struktur tanah yang gembur, sesuai dengan perkembangan akar tanaman cabai, menstabilkan peredaran air, udara, dan suhu di dalam tanah. Pengolahan lahan dilakukan dengan pencangkulan setelah dicangkul di angin-anginkan (berakan) selama satu minggu.

Pembuatan bedengan dilakukan setelah pengolahan lahan yakni mencangkul serta meratakan agar tanah tidak padat, setelah bedengan terbentuk kemudian pemberian pupuk kandang kambing 1 karung ukuran $25 \mathrm{~kg}$ untuk 1 bedengan dengan ukuran bedengan 1x10 meter kemudian ditambahkan pengapuran untuk mengurangi ke asaman tanah dan selanjutnya bedengan ditutup dengan mulsa.

Benih tanaman cabai sebelum disemai direndam 24 jam di dalam larutan Plant Catalist agar mempercepat berkecambah. Kemudian diletakkan pada kain yang lembab. Setelah benih berkecambah dipindahkan ke dalam polibag kecil. Media semai berupa campuran tanah yang telah diayak, pupuk kandang, seta pasir dengan perbandingan (1:1:1). Pemeliharaan bibit meliputi penyiraman, penyemprotan dengan pestisida curacron $2 \mathrm{ml} \mathrm{l}^{-1}$ dan pembersihan gulma. Bibit yang telah berumur 1 bulan, atau berdaun 6-7 helai dipindah ke lahan dan ditanam pada lubang yang berjarak $50 \mathrm{~cm}$ x $60 \mathrm{~cm}$ yang dilakukan sore hari agar tanaman tidak stres terkena cahaya matahari akibat pemindahan bibit ke lahan. Setiap lubang berisi satu bibit tanaman cabai setiap petak percobaan terdapat 6-8 tanaman dengan ukuran per petak percobaan $1 \times 2$ meter.

Pemeliharaan meliputi penyulaman, penyiraman, dan pencegahan gangguan hama dan penyakit serta pemupukan. Penyulaman dilakukan secepat mungkin agar tanaman tidak terlalu berbeda dengan tanaman lain, yaitu maksimum satu minggu setelah tanam dengan mengganti bibit yang mati atau tumbuh abnormal dengan bibit yang baik. Irigasi dilakukan untuk menjaga pertumbuhan tanaman yang dilakukan sesuai kondisi lapang, jika kering di lakukan irigasi dengan cara dialirkan keseluruh bedengan agar tanaman tidak kekurangan air. Pencegahan hama dan penyakit dengan penyemprotan pestisida setiap satu minggu sekali. Pemupukan dilakukan dengan pupuk NPK 16-16-16 dengan dosis 250 gram yang diberikan secara berkala yang dilarutkan dalam 10 liter air lalu dicampur dengan Plant Patalyst 2006 sebanyak dua sendok takar sabagai larutan stok. Kemudian diambil satu liter yang kemudian dilarutkan kembali dalam air sebanyak 10 liter air. Kemudian diberikan $250 \mathrm{ml}$ per tanaman cabai. Pemasangan ajir dilakukan pada tanaman berumur tujuh hari setelah tanam. Pemasangan ajir bertujuan untuk menjaga tanaman tidak roboh akibat hujan dan terpaan angin dengan panjang ajir sekitar $125 \mathrm{~cm}$.

Perlakuan aplikasi $\mathrm{KNO}_{3}$ dilakukan setelah bibit berumur 30 hari setelah tanam, konsentrasi dari masing -masing $\mathrm{KNO}_{3}$ yakni 0,2,4,6,8 $\mathrm{g} \mathrm{l}^{-1}$, diberikan dengan cara melarutkan masing-masing konsentrasi ke dalam 1 liter air sebagai larutan, dan pertanaman diberikan sebanyak $250 \mathrm{ml}$ per tanaman, pemberiannya dilakukan dengan cara disemprot dibagian daun. Aplikasi $\mathrm{KNO}_{3}$ diberikan seminggu sekali sebanyak 8 kali.

Variabel yang diamati yaitu tinggi tanaman $(\mathrm{cm})$, tingkat percabangan, bobot berangkasan $(\mathrm{g})$, jumlah bunga, jumlah buah panen per tanaman (buah), jumlah buah gugur, dan bobot buah per sampel tanaman $(\mathrm{g})$.

\section{HASIL DAN PEMBAHASAN}

Pengaruh aplikasi kalium nitrat terhadap pola pertumbuhan dan hasil tanaman cabai merah secara umum tidak berbeda nyata. Pola pertumbuhan tinggi tanaman dan tingkat percabangan tidak menunjukan pola linear maupun kuadratik yang nyata. Pola pertumbuhan pada jumlah bunga menunjukan hasil yang nyata secara linear pada pengamatan minggu ke-14 dan minggu ke18 dan secara kuadratik pada pengamatan minggu ke20. Pola pertumbuhan pada jumlah buah tidak nyata secara linear tetapi menunjukan hasil nyata secara kuadratik pada pengamatan minggu ke-18. Pola pertumbuhan pada buah gugur menunjukan hasil nyata secara linear pada pngamatan minggu ke-18, namun secara kuadratik tidak nyata (Tabel 1). Pada komponen hasil yaitu bobot panen pengaruh aplikasi kalium nitrat memberikan pengaruh nyata secara kuadratik pada panen minggu ke-23, tetapi secara linear tidak berpengaruh nyata (Tabel 2).Pada bobot berangkasan aplikasi kalium nitrat berpengaruh nyata sacara kuadratik dan secara linear tidak nyata (Tabel 3).

Hasil analisis menunjukkan bahwa pemberian beberapa konsentrasi kalium nitrat 0 , 2, 4, 6, $8 \mathrm{gl}^{-1}$ tidak memberikan pengaruh yang nyata terhadap tinggi tanaman cabai dan tingkat percabangan pada seluruh pengamatan.

Hasil menunjukkan bahwa pemberian beberapa konsentrasi kalium nitrat memberikan pengaruh yang 
Tabel 1. Rekapitulasi pengaruh konsentrasi kalium nitrat terhadap tinggi tanaman, tingkat percabangan, jumlah bunga, jumlah buah, dan buah gugur.

\begin{tabular}{|c|c|c|c|c|c|c|c|c|c|}
\hline \multirow{2}{*}{$\begin{array}{c}\text { Variabel } \\
\text { pengamatan }\end{array}$} & & \multicolumn{8}{|c|}{ Minggu setelah tanam } \\
\hline & & 6 & 8 & 10 & 12 & 14 & 16 & 18 & 20 \\
\hline Bobot & Linier & \multicolumn{8}{|c|}{ tn } \\
\hline brangkasan & Kuadratik & & & & & & & & \\
\hline Tinggi & Linier & tn & tn & tn & tn & tn & tn & tn & tn \\
\hline Tanaman & Kuadratik & tn & tn & tn & tn & tn & tn & tn & tn \\
\hline Tingkat & Linier & tn & tn & tn & tn & tn & tn & tn & $\mathrm{tn}$ \\
\hline Percab angan & Kuadratik & tn & tn & tn & tn & tn & tn & tn & tn \\
\hline \multirow{2}{*}{ Jumlah bunga } & Linier & - & tn & tn & tn & $*$ & tn & $*$ & $\mathrm{tn}$ \\
\hline & Kuadratik & - & tn & tn & tn & tn & tn & tn & $*$ \\
\hline \multirow{2}{*}{ Jumlah buah } & Linier & - & - & tn & tn & $\mathrm{tn}$ & tn & tn & tn \\
\hline & Kuadratik & - & - & tn & tn & tn & tn & $*$ & $\mathrm{tn}$ \\
\hline \multirow[t]{2}{*}{ Buah gugur } & Linier & - & - & tn & tn & tn & tn & $*$ & $\mathrm{tn}$ \\
\hline & Kuadratik & - & - & tn & tn & tn & tn & tn & tn \\
\hline
\end{tabular}

Tabel 2. Rekapitulasi pengaruh aplikasi kalium nitrat terhadap bobot panen.

\begin{tabular}{|c|c|c|c|c|c|c|c|c|c|c|c|}
\hline \multirow{2}{*}{$\begin{array}{c}\text { Variabel } \\
\text { pengamatan }\end{array}$} & & \multicolumn{10}{|c|}{ Minggu setelah tanam } \\
\hline & & 17 & 18 & 19 & 20 & 21 & 22 & 23 & 24 & 25 & 26 \\
\hline Bobot Panen & Linier & $\operatorname{tn}$ & tn & tn & tn & tn & tn & tn & tn & tn & tn \\
\hline & Kuadratik & $\operatorname{tn}$ & tn & tn & tn & tn & tn & $*$ & $\operatorname{tn}$ & tn & tn \\
\hline
\end{tabular}

Tabel 3. Pengaruh pemberian kalium nitrat terhadap bobot berangkasan.

\begin{tabular}{lc}
\hline Variable pengamatan & Bobot brangkasan \\
\hline Linier & tn \\
Kuadratik & $*$ \\
\hline
\end{tabular}

nyata terhadap jumlah bunga tanaman cabai pada pengamatan minggu ke-14 dan 18 namun dari kelima konsentrasi yang digunakan memberikan pengaruh yang sama terhadap jumlah bunga. Pada minggu ke-20 pemberian konsentrasi kalium nitrat $4 \mathrm{~g} \mathrm{l}^{-1}$ mulai memberikan peningkatan terhadap jumlah bunga. Ratarata jumlah bunga tanaman cabai pada pengamatan minggu ke-8 sebesar 36,95, minggu ke-10 sebesar 48,80, minggu ke-12 sebesar 71,63, minggu ke-14 sebesar 85,59 , minngu ke-16 sebesar 89,08, minggu ke-18 sebesar 81,39 , minggu ke-20 sebesar 65,42 bunga per pohon (Tabel 4).

Pengamatan pada minggu ke-18 pemberian konsentrasi kalium nitrat meningkatkan jumlah buah tanaman cabai pada konsentrasi $8 \mathrm{~g} \mathrm{l}^{-1}$ (Gambar 1). Ratarata jumlah buah tanaman cabai pada pengamatan minggu ke-10 sebesar 11,14, minggu ke-12 sebesar 21,34, minggu ke-14 sebesar 30,40, minggu ke-16 sebesar 39,48, minggu ke-18 sebesar 47,24, dan minggu ke-20 sebesar 49,63 buah dipohon (Tabel 5)

Pemberian beberapa konsentrasi kalium nitrat pada pengamatan minggu ke- 18 memberikan pengaruh yang nyata terhadap jumlah buah gugur tanaman cabai. Namun, dari kelima konsentrasi Kalium Nitrat memberikan pengaruh yang sama terhadap buah gugur tanaman cabai. Rata-rata jumlah buah cabai gugur pada minggu ke-10 sebanyak 0,64 buah, minggu ke-12 sebanyak 1,06, minggu ke-14 sebanyak 1,11, minggu ke16 sebanyak 1,74 , minggu ke-18 sebanyak 1,89 , dan pada minggu ke-20 sebanyak 1,96 buah (Tabel 6)

Pada pengamatan bobot buah sampai akhir panen pemberian konsentrasi kalium nitrat konsentrasi $6 \mathrm{~g} \mathrm{l}^{-1}$ menunjukan hasil tertinggi pada bobot total. Rata-rata jumlah panen tanaman cabai pada panen minggu ke-17 sebesar $9 \mathrm{~g}$, panen minggu ke-18 sebesar 8,51 g, minggu ke-19 sebesar 16,05 g, minggu ke-20 sebesar 9,88 g, 
Tabel 4. Pengaruh konsentrasi kalium nitrat terhadap jumlah bunga tanaman cabai.

\begin{tabular}{|c|c|c|c|c|c|c|c|c|}
\hline \multirow{2}{*}{\multicolumn{2}{|c|}{$\begin{array}{l}\text { Pola respon } \\
\text { dan perlakuan }\end{array}$}} & \multicolumn{7}{|c|}{ Pengamatan ming gu ke- } \\
\hline & & 8 & 10 & 12 & 14 & 16 & 18 & 20 \\
\hline \multirow{4}{*}{$\begin{array}{l}\text { Linear } \\
\text { Kuadratik }\end{array}$} & & tn & $\operatorname{tn}$ & tn & $*$ & $\operatorname{tn}$ & $*$ & tn \\
\hline & & tn & tn & $\operatorname{tn}$ & $\operatorname{tn}$ & tn & tn & $*$ \\
\hline & K 0 & 29,12 & 45,72 & 70,19 & 76,78 & 85,38 & 74,72 & 60,94 \\
\hline & K 1 & 36,51 & 49,24 & 66,99 & 73,36 & 82,58 & 74,39 & 61,20 \\
\hline \multirow[t]{3}{*}{ Perlakuan } & $\mathrm{K} 2$ & 40,64 & 46,70 & 73,10 & 89,34 & 87,82 & 80,08 & 65,55 \\
\hline & K 3 & 40,90 & 50,52 & 74,39 & 92,94 & 94,49 & 90,20 & 68,76 \\
\hline & $\mathrm{K} 4$ & 37,57 & 51,81 & 73,49 & 95,51 & 95,11 & 87,58 & 70,64 \\
\hline \multicolumn{2}{|l|}{$\mathrm{R}$ ata-rata } & 36,95 & 48,80 & 71,63 & 85,59 & 89,08 & 81,39 & 65,42 \\
\hline
\end{tabular}

Keterangan: $\mathrm{K} 0=$ tanpa kalium nitrat, $\mathrm{K} 1=$ taraf konsentrasi kalium nitrat $2 \mathrm{~g} \mathrm{l}^{-1}, \mathrm{~K} 2=$ taraf konsentrasi kalium nitrat $4 \mathrm{~g} \mathrm{l}^{-1}, \mathrm{~K} 3=$ taraf konsentrasi kalium nitrat $6 \mathrm{~g} \mathrm{l}^{-1}, \mathrm{~K} 4=$ taraf konsentrasi kalium nitrat $8 \mathrm{~g} \mathrm{l}^{-1}$.

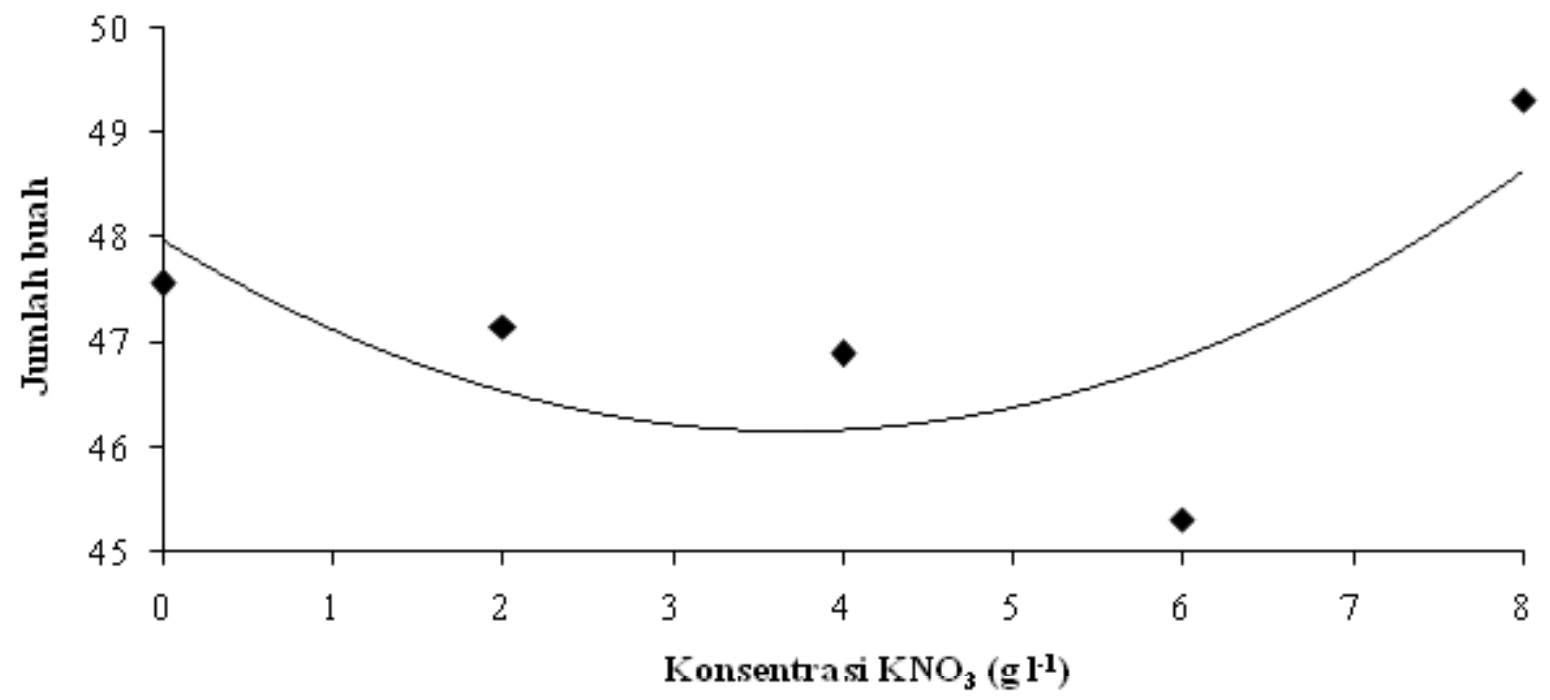

Gambar 1. Hubungan antara konsentrasi kalium nitrat dengan jumlah buah tanaman cabai pada pengamatan minggu ke-18 mst. $y=0,133 x^{2}-0,988 x+47,87 ; R^{2}=0,521$.

Tabel 5. Pengaruh konsentrasi kalium nitrat terhadap jumlah buah tanaman cabai.

\begin{tabular}{|c|c|c|c|c|c|c|c|}
\hline \multirow{2}{*}{$\begin{array}{l}\text { Pola respon } \\
\text { dan perlakuan }\end{array}$} & & \multicolumn{5}{|c|}{ Penga matan $m$ inggu ke- } & \multirow[b]{2}{*}{20} \\
\hline & & 10 & 12 & 14 & 16 & 18 & \\
\hline \multirow{2}{*}{$\begin{array}{l}\text { Linear } \\
\text { Kuadratik }\end{array}$} & & $\operatorname{tn}$ & $\operatorname{tn}$ & tn & $\operatorname{tn}$ & $\operatorname{tn}$ & $\operatorname{tn}$ \\
\hline & & tn & tn & tn & $\operatorname{tn}$ & $*$ & $\operatorname{tn}$ \\
\hline \multirow{5}{*}{ Perlaku an } & K0 & 9,58 & 21,00 & 29,56 & 37,64 & 47,56 & 46,58 \\
\hline & $\mathrm{K} 1$ & 10,64 & 21,25 & 30,03 & 39,17 & 47,14 & 51,47 \\
\hline & $\mathrm{K} 2$ & 11,89 & 22,92 & 30,75 & 40,33 & 46,89 & 47,67 \\
\hline & K3 & 13,11 & 22,31 & 30,75 & 38,50 & 45,31 & 49,92 \\
\hline & $\mathrm{K} 4$ & 10,47 & 19,22 & 30,92 & 41,75 & 49,31 & 52,53 \\
\hline Rata-rata & & 11,14 & 21,34 & 30,40 & 39,48 & 47,24 & 49,63 \\
\hline
\end{tabular}

Keterangan: $\mathrm{K} 0=$ tanpa kalium nitrat, $\mathrm{K} 1=$ taraf konsentrasi kalium nitrat $2 \mathrm{~g} \mathrm{l}^{-1}, \mathrm{~K} 2=$ taraf konsentrasi kalium nitrat $4 \mathrm{~g} \mathrm{l}^{-1}, \mathrm{~K} 3=$ taraf konsentrasi kalium nitrat $6 \mathrm{~g} \mathrm{l}^{-1}, \mathrm{~K} 4=$ taraf konsentrasi kalium nitrat $8 \mathrm{~g} \mathrm{l}^{-1}$. 
minggu ke-21 sebesar 16,22 g, minggu ke-22 sebesar $11,10 \mathrm{~g}$, minggu ke-24 sebesar 9,74 g, minggu ke-25 sebesar 7,51 g, dan minggu ke-26 sebesar 6,61 g (Tabel $7)$.

Dari hasil penelitian yang telah dilaksanakan, pemberian berbagai konsentrasi kalium nitrat yang diberikan tidak berpengaruh terhadap pola pertumbuhan tanaman cabai pada fase vegetatatif tanaman yaitu pada tinggi tanaman dan tingkat percabangan dari berbagai konsentrasi tersebut memberikan pola yang sama.sedangkan pada bobot berangkasan pemberian kalium nitrat $6 \mathrm{~g} \mathrm{l}^{-1}$ memiliki bobot kering tanaman yang cenderung lebih ringan di bandingkan dengan konsentrasi yang lainnya, pada variabel pengamatan jumlah bunga dan jumlah buah di pohon konsentrasi 4, 6, $8 \mathrm{gl}^{-1}$ dapat memberikan peningkatan yang cukup baik, pada jumlah buah gugur masing masing konsentrasi memberikan pengaruh yang relatif sama tetapi pada pengamatan minggu ke-18 jumlah buah gugur tanpa pemberian kalium nitrat lebih banyak dibandingkan dengan yang diberikan kalium nitrat, pada komponen hasil yakni bobot buah pengaruh lebih baik ditunjukan pada pemberian konsentrasi $6 \mathrm{~g} \mathrm{l}^{-1}$ dan $8 \mathrm{~g} \mathrm{l}^{-1}$.

Tetapi pada jumlah bunga dan jumlah buah pemberian kalium nitrat konsentrasi 4, 6, $8 \mathrm{~g} \mathrm{l}^{-1}$ mampu menunjukan hasil yang lebih baik sehingga mampu menghasilkan rata-rata jumlah bunga dan jumlah buah lebih tinggi dibandingkan tanpa diberi kosentrasi dan konsentrasi $2 \mathrm{~g} \mathrm{l}^{-1}$. Hal ini sejalan dengan hasil penelitian Andriani (2008) menunjukkan bahwa kalium nitrat (KNO3) dapat meningkatkan pertumbuhan, jumlah bunga, jumlah buah, dan produktivitas buah cabai merah. Kalium merupakan pengaktif dari sejumlah besar enzim yang penting untuk respirasi dan fotosintesis (Salisbury

Tabel 6. Pengaruh konsentrasi kalium nitrat terhadap jumlah buah gugur tanaman pada minggu ke-10, 12, 14, 16, $18,20 \mathrm{mst}$.

\begin{tabular}{lccccccc}
\hline \multirow{2}{*}{$\begin{array}{l}\text { Pola respon } \\
\text { dan perlakuan }\end{array}$} & & \multicolumn{7}{c}{ Pengamatan minggu ke- } \\
\cline { 2 - 7 } & & 10 & 12 & 14 & 16 & 18 & 20 \\
\hline Linear & & tn & tn & tn & tn & $*$ & tn \\
Kuadratik & & tn & tn & tn & tn & tn & tn \\
& K0 & 0,67 & 1,06 & 1,00 & 1,67 & 2,81 & 2,42 \\
Perlaku an & $\mathrm{K} 1$ & 0,53 & 1,06 & 0,94 & 1,91 & 1,53 & 1,75 \\
& $\mathrm{~K} 2$ & 0,72 & 1,11 & 1,17 & 1,53 & 1,97 & 1,97 \\
& $\mathrm{~K} 3$ & 0,64 & 1,11 & 1,39 & 1,72 & 1,53 & 1,86 \\
& $\mathrm{~K} 4$ & 0,67 & 0,94 & 1,06 & 1,89 & 1,61 & 1,81 \\
\hline Rata-rata & & 0,64 & 1,06 & 1,11 & 1,74 & 1,89 & 1,96 \\
\hline
\end{tabular}

Keterangan: $\mathrm{K} 0=$ tanpa kalium nitrat, $\mathrm{K} 1=$ taraf konsentrasi kalium nitrat $2 \mathrm{~g} \mathrm{l}^{-1}, \mathrm{~K} 2=$ taraf konsentrasi kalium nitrat $4 \mathrm{~g} \mathrm{l}^{-1}, \mathrm{~K} 3=$ taraf konsentrasi kalium nitrat $6 \mathrm{~g} \mathrm{l}^{-1}, \mathrm{~K} 4=$ taraf konsentrasi kalium nitrat $8 \mathrm{~g} \mathrm{l}^{-1}$.

Tabel 7. Pengaruh konsentrasi kalium nitrat terhadap bobot buah tanaman cabai pada pengamatan minggu ke17 sampai dengan 26 mst.

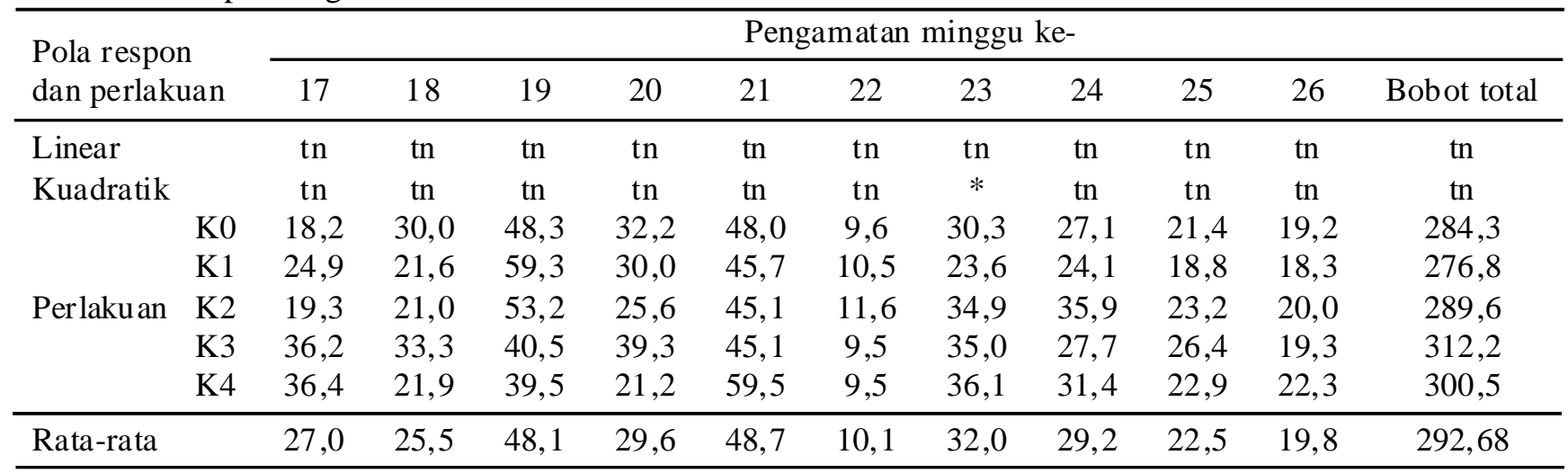

Keterangan: $\mathrm{K} 0=$ tanpa kalium nitrat, $\mathrm{K} 1=$ taraf konsentrasi kalium nitrat $2 \mathrm{~g} \mathrm{l}^{-1}, \mathrm{~K} 2=$ taraf konsentrasi kalium nitrat $4 \mathrm{~g} \mathrm{l}^{-1}, \mathrm{~K} 3=$ taraf konsentrasi kalium nitrat $6 \mathrm{~g} \mathrm{l}^{-1}, \mathrm{~K} 4=$ taraf konsentrasi kalium nitrat $8 \mathrm{~g} \mathrm{l}^{-1}$. 
dan Ross, 1995). Nitrogen merupakan komponen utama klorofil, protein, asam amino, dan enzim. Nitrogen diperlukan untuk pertumbuhan daun dan batang, pertunasan, pembentukan klorofil, meningkatkan serapan unsur hara, dan pengaruhnya penting terhadap peningkatan hasil (Sumarwoto dan Widodo, 2008).

Dalam hubungannya aktivator pembentukan karbohidrat, kalium dalam KNO3 sangat diperlukan pada fase reproduktif tanaman. Untuk menghasilkan kualitas bunga dan buah yang lebih baik, akibat pembentukan gula yang semakin sempurna. Penambahan kalium yang tinggi pada fase generatif tanaman akan meningkatkan kualitas hasil (Cahyono dan Ismail, 1999 dalam Handayani, 2006). Dari hasil penelitian, pengaruh kalium nitrat mampu meningkatkan komponen hasil yakni pada pengamatan bobot buah yang berpengaruh nyata pada panen di minggu ke-23 dengan konsentrasi $4 \mathrm{~g} \mathrm{l}^{-1}$ dan pada bobot total panen konsentrasi $6 \mathrm{~g} \mathrm{l}^{-1}$ menunjukan jumlah yang lebih tinggi dibandingkan konsentrasi lain nya.

Kondisi awal pertanaman di musim hujan dimana lahan tempat pertanaman cabai tergenang oleh air akibat hujan yang terjadi serta aliran air yang mengalir kemudian terhenti akibat terdapat bendungan di petakan lahan, oleh kerena tergenang nya lahan maka dapat mempengaruhi reaksi akar tanaman cabai, tanaman cabai yang masih muda cenderung sangat rentan oleh pengaruh lingkungan apabila tanaman terlalu lama tergenang oleh air yang berlebihan unsur hara yang ada di tanah dapat tercuci sehingga tidak dapat di manfaatkan oleh tanaman cabai untuk pertumbuhan, kalium nitrat yang seharus nya dapat dimanfaatkan oleh tanaman hanya terjerat didalam tanaman yang tidak bisa dimanfaatkan dalam proses fisiologis tanaman.

Menurut Gunadi dan Sumiati (1990) bagian daun merupakan tempat terjadinya pada proses fotosintesis tanaman dimana proses tersebut memerlukan cahaya matahari untuk memproduksi krbohidrat sebagai bahaun baku pertumbuhan dan perkembangan tanaman selanjutnya, tetapi pada saat penelitian dilakukan di musim hujan yang cenderung keadaan mendung kurang nya cahaya matahai untuk membantu mengaktifkan fungsi kalium sebagai pengaktivator berbagai enzim guna memaksimalkan proses penyerapan hara maupun proses pemanfaatan hara bagi tubuh tanaman. Selain dari itu jumlah pupuk dasar NPK yang diberika pada penelitian ini relatif masih sangat rendah yaitu berkisar 1,5 - $2 \mathrm{~g}$ per tanaman selama perawatan tanaman. Menurut Prajnanta (2007), kebutuhan tanaman cabai sebesar 100 g per tanaman, hal ini menjadi salah satu faktor kekurangan asupan hara yang diperlukan tanaman terhadap kebutuhan pupuk dasar. Menurut Allabi (2005) dan Chellemi tanaman cabai memerlukan unsur hara makro dan mikro untuk pertumbuhan dan peningkatan produksinya.

Pada hasil penelitian pola pertumbuhan yang ditunjukan pada fase vegetatif yang dapat diliahat pada pengamatan tinggi tanaman serta tingkat percabangan tanaman tiap konsentrasi antara 0,2, 4, 6, 8, $\mathrm{g} \mathrm{l}^{-1}$ memberikan pengaruh yang tidak nyata, pola pertumbuhan yang kontiniu meningkat hingga akhir pengamatan secara periodik. Untuk indikator produksi tanaman pada jumlah bunga dan jumlah buah konsentrasi 4, 6, $8 \mathrm{~g} \mathrm{l}^{-1}$ mampu memberikan hasil yang lebih tinggi dibandingkan konsentrasi $0 \mathrm{~g} \mathrm{l}^{-1}$ dan $2 \mathrm{~g} \mathrm{l}^{-1}$ serta pada bobot buah total panen konsentrasi $6 \mathrm{~g} \mathrm{l}^{-1}$ mampu menghasilkan jumlah yang lebih tinggi dibandingkan dengan konsentrasi $0,2,4$, dan $8 \mathrm{~g} \mathrm{l}^{-1}$. Sedangkan bobot berangkasan kosentrasi $6 \mathrm{~g} \mathrm{l}^{-1}$ memiliki bobot yang rendah dibandingkan dengan konsentrasi lainnya.

\section{KESIMPULAN}

Berdasarkan hasil penelitian dapat disimpulkan bahwa pada pertumbuhan vegetatif untuk variabel tinggi tanaman, tingkat percabangan, dan bobot berangkasan pemberian kalium nitrat pada berbagai konsentrasi tidak berbeda. Pada pemberian konsentrasi kalium nitrat memberikan respon terhadap komponen hasil pada konsentrasi kalium nitrat 4, 6, $8 \mathrm{gl}^{-1}$ menghasilkan jumlah bunga di tanaman cabai, tetapi jumlah buah tertinggi/ terbanyak terdapat pada konsentrasi $8 \mathrm{~g} \mathrm{l}^{-1}$, sedangkan pada bobot buah total konsentrasi $6 \mathrm{~g} \mathrm{l}^{-1}$ memberikan hasil yang lebih tinggi.

\section{DAFTAR PUSTAKA}

Allabi D.A. 2005. Effect of fertilizer phosphorus and poultry droppings treatments on growth and nutrient components of pepper (Capsicum annum L) African. J. Biotech. 5(8):671-677.

Andriani, R. 2008. Pengaruh Bentuk Senyawa Nitrogen Terhadap Perkembangan Generatif dan Produktivitas Cabai Merah (Capsicum annum L). Skripsi. Institut Teknologi Bandung.

Chellemi, D.O., G. Lazarovits. 2002. Effect of Organic Fertilizer Applications on Growth Yield and Pests of Vegetable Crops. Proc Fla State Hort Soc. 115:315-321. 
Gunadi, N. dan E. Sumiati. 1990. Pengaruh Waktu Aplikasi dan Dosis Pupuk N. P. K. terhadap Hasil Lombok dalam Sistem Tumpangsari dengan Kacang Gog dan Selada. Buletin Penelitian Hortikultura. XIX(2):78-79.

Handayani, Y. 2006. Pengaruh Konsentrasi Kalium Nitrat $\left(\mathrm{KNO}_{3}\right)$ terhadap Pertumbuhan dan Pembungaan Tanaman Spathiphyllum wallisii Schoot Fase Generatif. Skripsi. Fakultas Pertanian Universitas Lampung.

Prajnanta, F. 2007. Agribisnis Cabai Hibrida. Penebar Swadaya. Jakarta.
Rukmana, R. 1996. Usaha Tani Cabai Hibrida Sistem Mulsa Plastik. Kanisius. Yogyakarta.

Salisbury, F.B. dan C.W. Ross. 1995. Fisiologi Tumbuhan, jilid II. (diterjemahkan dari: Plant Physiology, 4th edition, penterjemah: D.R. Lukman dan Sumaryono). Penerbit Institut Teknologi Bandung. Bandung. 173 hal.

Sumarwoto, W. 2008. Pertumbuhan dan Hasil Elephant Food Yam (Amorphophallus muelleri Blume) Periode Tumbuh Pertama pada Berbagai Dosis Pupuk N dan K. Agrivita 30:29-37 